\title{
Sistem Waris Dalam Perspektif Islam dan Peraturan Perundang-undangan Di Indonesia*
}

(Heritage System in Islamic Perspectives and Legal Regulations In Indonesia)

\author{
Afidah Wahyuni ${ }^{1}$ \\ Universitas Islam Negeri Syarif Hidayatullah Jakarta \\ DOI: $10.15408 /$ sjsbs.v5i2.9412
}

\begin{abstract}
:
Inheritance law according to Islamic law is one part of family law (al-Ahwalus Syahsiyah). This science is very important to learn so that in the implementation of the division of inheritance there is no mistake and can be carried out as fairly as possible, because by studying the Islamic inheritance law for Muslims, will be able to fulfill the rights relating to inheritance after being abandoned by Muwarris (heir) and submitted to the heirs who have the right to receive it. Thus, one can avoid sin, namely not eating the property of people who are not their rights, because there is no fulfillment of Islamic law regarding inheritance. The inheritance legal system according to the Civil Code does not distinguish between sons and daughters, between husbands and wives, they have the right to inheritance, and the sons share sons and daughters, the part of a wife or husband is the same as the child. When linked to the hereditary system, the Civil Code adheres to a bilateral descent system, where each person connects himself to the descendants of his father and mother, meaning that heirs are entitled to inherit from the father if the father dies and has the right to inherit from the mother if the mother dies.
\end{abstract}

Keywords: Inheritance System, Islamic Law, Indonesian Legislation

\begin{abstract}
Abstrak:
Hukum Kewarisan menurut hukum Islam merupakan salah satu bagian dari hukum keluarga (al-Ahwalus Syahsiyah). Ilmu ini sangat penting dipelajari agar dalam pelaksanaan pembagian harta waris tidak terjadi kesalahan dan dapat dilaksanakan dengan seadil-adilnya, sebab dengan mempelajari hukum kewarisan Islam bagi umat Islam, akan dapat menunaikan hak-hak yang berkenaan dengan harta waris setelah ditinggalkan oleh muwarris (pewaris) dan disampaikan kepada ahli waris yang berhak untuk menerimanya. Dengan demikian, seseorang dapat terhindar dari dosa yakni tidak memakan harta orang yang bukan haknya, karena tidak ditunaikannya hukum Islam mengenai kewarisan. Sistem hukum kewarisan menurut KUHPerdata tidak membedakan antara anak laki-laki dan anak perempuan, antara suami dan isteri, mereka berhak terhadap harta warisan, dan bagian anak laki-laki sama dengan bagian anak perempuan, bagian seorang isteri atau suami sama dengan bagian anak. Apabila dihubungkan dengan sistem keturunan, maka KUHPerdata menganut sistem keturunan bilateral, dimana setiap orang itu menghubungkan dirinya dengan keturunan ayah maupun ibunya, artinya ahli waris berhak mewaris dari ayah jika ayah meninggal dan berhak mewaris dari ibu jika ibu meninggal.
\end{abstract}

Kata Kunci: Sistem Waris, Hukum Islam, Perundang-undangan Indonesia

*Diterima: 10 April 2018, Revised: 16 April 2018, Diterima: 20 Juni 2018.

1 Afidah Wahyuni adalah dosen tetap Fakultas Syariah dan Hukum, Universitas Islam Negeri Syarif Hidayatullah Jakarta. E-mail: afidah.wahyuni@gmail.com. 


\section{Pendahuluan}

Hukum kewarisan Islam mengatur peralihan harta dari seseorang yang telah meninggal kepada yang masih hidup. Aturan tentang peralihan harta ini disebut dengan berbagai nama. Dalam literatur hukum Islam ditemukan beberapa istilah untuk menamakan hukum kewarisan seperti seperti: Faraid, Fiqih Mawaris, dan hukmal-Waris. ${ }^{2}$ Perbedaan dalam penamaan ini terjadi karena perbedaan arah yang dijadikan titik utama dalam pembahasan. Namun kata yang lazim dipakai adalah faraid sebagaimana digunakan oleh an-Nawawi dalam kitab Mihaj alThalibin.

Pada dasarnya waris dalam Islam merupakan suatu yang tak terpisahkan, oleh karena itu, untuk mengaktualisasikan dalam Islam, maka eksistensinya harus dijabarkan dalam bentuk faktual. Dalam hal ini, pelaksanaan hukum kewarisan harus kelihatan dalam sistem keluarga yang berlaku dalam masyarakat. ${ }^{3}$ Dari seluruh hukum yang berlaku dalam masyarakat, maka hukum perkawinan dan kewarisanlah yang menentukan dan mencerminkan sistem kekeluargaan ${ }^{4}$ yang sekaligus merupakan salah satu bagian dari hukum perdata.

Di awal perkembangan dan pertumbuhan Islam, Nabi Muhammad adalah idola yang ideal untuk menyelesaikan masalah hukum kewarisan karena beliau menduduki posisi paling istimewa, beliau berfungsi menafsirkan dan menjelaskan hukum berdasarkan wahyu yang turun pada beliau. Kemudian beliau berwenang pula membuat hukum kewarisan di luar dari wahyu. ${ }^{5}$ Sehingga lahirlah hadits sebagai perkataan, hal ihwal, pengalaman, dan taqrir Nabi Muhammad SAW ${ }^{6}$ setelah beliau wafat.

Kenyataan sejarah umat Islam dalam perkembangan pemikiran mereka tentang pelaksanaan kewarisan ternyata beragam. Islam sebagai sistem nilai turut mempengaruhi umat Islam untuk mengamalkan ajaran kewarisan yang terdapat dalam al-Qur'an. Islam tidak hanya mengatur manusia dengan Tuhan, tetapi Islam juga mengatur hubungan manusia dengan sesamanya. Bahkan Islam memerintahkan agar umat Islam mengikuti aturan Islam secara keseluruhan dan melarang mengikuti kehendak setan.

Abu Bakar sebagai khalifah pertama sekaligus ulama pernah memutuskan bahwa semua harta peninggalan diwarisi oleh nenek dari ibu meskipun ia bersama nenek dari ayah. Demikian pula Umar bin Khattab, khalifah kedua, pada

2 Amir Syarifuddin, Hukum Kewarisan Islam, (Jakarta: Kencana, 2004), h. 5.

3 Ali Parman, Kewarisan dalam Al-Qur'an: Suatu Kajian Hukum dengan Pendekatan Tafsir Tematik, (Jakarta: PT RajaGrafindoPersada, 1995), h.1

${ }^{4}$ Hazairin, Hukum Kewarisan Bilateral menurut Al-Qur'an dan Hadis, (Jakarta: Tinta Mas, 1982), h. 11.

${ }^{5}$ Ali Parman, Kewarisan dalam Al-Qur'an: Suatu Kajian Hukum dengan Pendekatan Tafsir Tematik, h. 1.

${ }^{6}$ M. Shuhudi Ismail, Kaidah Keshahihan Sanad Hadis, (Jakarta: Bulan Bintang, 1988), h. 3. 
awalnya hanya memberikan saham kepada ahli waris: suami, ibu, dan dua saudara laki-laki seibu tanpa memberikan warisan kepada saudara laki-laki sekandung. Pertimbangan Umar adalah bahwa ketiga jenis ahli waris itu mendapat warisan dari sisa harta yang ditentukan dalam Al-Qur'an, sedang ahli waris yang satu hanya mendapat warisan dari sisa harta karena ia tidak ditentukan warisannya dalam Al-Qur'an. ${ }^{7}$ Akan tetapi beberapa waktu kemudian saudara sekandung tersebut mengajukan keberatan bahwa paling tidak semua ahli waris mempunyai ibu yang sama dari pewaris. Dengan demikian, meskipun mempunyai hubungan kekeluargaan yang sama dengan saudara seibu. Bahkan dari segi kedekatan dengan pewaris, saudara sekandung mempunyai hak yang lebih besar dari pada saudara seibu. Logika tersebut diterima oleh Umar sehingga saudara sekandung dapat berbagi rata dengan saudara seibu. Sikap kompromi dalam hal tersebut dikenal dalam sejarah hukum kewarisan sebagai kasus himariyah. Dalam kasus lain Ali bin Abi Thalib, khalifah keempat, yang mula-mula mengurangi nilai warisan para ahli waris secara proporsional karena warisanwarisan yang telah ditetapkan dalam al-Qur'an ternyata melebihi ketentuan. Dalam hal ini, Ali memberikan warisan kepada istri kurang dari nilai warisan yang ditentukan. Dengan demikian, ahli waris: dua anak perempuan, ayah, dan ibu secara otomatis berkurang nilainya secara proporsional. ${ }^{8}$

\section{Kepemilikan Harta Dalam Islam}

Menurut pandangan Islam hak milik dibedakan menjadi tiga kelompok, yaitu: hak milik pribadi, hak milik umum, dan hak milik negara. ${ }^{9}$

\section{Kepemilikan Individu (Private Property)}

Kepemilikan individu adalah ketetapan hukum syara' yang berlaku bagi dzat ataupun manfaat (jasa) tertentu, yang memungkinkan siapa saja yang mendapatkannya untuk memanfaatkan barang tersebut, individu memiliki hak untuk memiliki harta ${ }^{10}$ serta memperoleh kompensasi jika barangnya diambil kegunaannya oleh orang lain seperti disewa, ataupun karena dikonsumsi untuk dihabiskan dzatnya. Sebab-sebab kepemilikan tersebut terbatas pada lima sebab berikut ini: a). Bekerja, b). Warisan, c). Kebutuhan akan harta untuk menyambung hidup, d). Harta pemberian negara yang diberikan kepada rakyat,

7 Ali Parman, Kewarisan dalam Al-Qur'an: Suatu Kajian Hukum dengan Pendekatan Tafsir Tematik, h. 3 .

8 Ali Parman, Kewarisan dalam Al-Qur'an: Suatu Kajian Hukum dengan Pendekatan Tafsir Tematik, h. 3 .

${ }_{9}^{9}$ Ali Akbar, "Konsep Kepemilikan Dalam Islam ", dalam Jurnal Ushuluddin, Vol XVIII No. 2, Juli 2012, h. 131.

${ }^{10}$ Nawi Bin Abdullah, “Konsep Kepemilikan dalam Islam”, dalam Jurnal Usuluddin, Bil 19 2004, h. 25. 
e). Harta-harta yang diperoleh oleh seseorang dengan tanpa mengeluarkan harta atau tenaga apapun. ${ }^{11}$

Setiap individu memiliki hak untuk menikmati hak miliknya, menggunakannya secara produktif, memindahkannya dan melindunginya dari pemubaziran. Namun pemilik juga terkena sejumlah kewajiban tertentu, seperti membantu dirinya sendiri dan kerabatnya serta membayar sejumlah kewajiban.

\section{Kepemilikan Umum (Collective Property)}

Kepemilikan umum adalah izin Syari' kepada suatu komunitas untuk sama-sama memanfaatkan benda. Sedangkan benda-benda yang termasuk dalam kategori kepemilikan umum adalah benda-benda yang telah dinyatakan oleh Allah Subhanahu Wa Ta'ala dan Rasulullah Shallallahu Alaihi Wasallam bahwa benda-benda tersebut untuk suatu komunitas dimana mereka masing-masing saling membutuhkan. Berkaitan dengan pemilikan umum ini, hukum Islam melarang benda tersebut dikuasai hanya oleh seseorang saja. Atas dasar pengertian di atas maka benda-benda yang termasuk dalam kepemilikan umum dapat dikelompokkan menjadi tiga kelompok; ${ }^{12}$

Pertama, Benda-benda yang merupakan fasilitas umum. Bentuk fasilitas umum adalah apa saja yang dianggap sebagai kepentingan manusia secara umum. Rasulullah Shallallahu Alaihi Wasallam telah menjelaskan dalam sebuah hadits bagaimana sifat fasilitas umum tersebut.

Kedua, Bahan tambang yang jumlahnya sangat besar. Bahan tambang dapat diklasifikasikan menjadi dua, yaitu: Barang tambang yang sedikit (terbatas) jumlahnya termasuk milik pribadi, serta boleh dimiliki secara pribadi, dan terhadap bahan tambang tersebut diberlakukan hukum rikaz (barang temuan), yang darinya harus dikeluarkan khumus, yakni seperlima bagiannya (20\%). Adapun bahan tambang yang sangat banyak (hampir tidak terbatas) jumlahnya, yang tidak mungkin dihabiskan oleh individu, maka bahan tambang tersebut termasuk milik umum (collective property), dan tidak boleh dimiliki secara pribadi. ${ }^{13}$

Ketiga, Benda-benda yang sifat pembentukannya menghalangi untuk dimiliki oleh individu secara perorangan. Benda yang dapat dikategorikan sebagai kepemilikan umum yaitu jalan raya, sungai, masjid dan fasilitas umum lainnya. Benda-benda ini dari merupakan fasilitas umum dan hampir sama dengan kelompok pertama. Namun meskipun benda-benda tersebut seperti jenis yang pertama, tetapi berbeda dari segi sifatnya, bahwa benda tersebut tidak bisa dimiliki oleh individu. Barang-barang kelompok pertama dapat dimiliki oleh individu jika jumlahnya kecil dan tidak menjadi sumber kebutuhan suatu

${ }^{11}$ Ali Akbar, “Konsep Kepemilikan Dalam Islam “, dalam Jurnal Ushuluddin, h. 131.

${ }^{12}$ Ali Akbar, “Konsep Kepemilikan Dalam Islam “, dalam Jurnal Ushuluddin, h. 131.

${ }^{13}$ Nawi Bin Abdullah, “Konsep Kepemilikan dalam Islam”, dalam Jurnal Usuluddin, h. 25. 
komunitas. Misalnya sumur air, mungkin saja dimiliki oleh individu, namun jika sumur air tersebut dibutuhkan oleh suatu komunitas maka individu tersebut dilarang memilikinya. Berbeda dengan jalan raya, mesjid, sungai dan lain-lain yang memang tidak mungkin dimiliki oleh individu. ${ }^{14}$

\section{Kepemilikan Negara (State Property)}

Harta-harta yang termasuk milik negara adalah harta yang merupakan hak seluruh kaum muslimin yang pengelolaannya menjadi wewenang negara, di mana negara dapat memberikan kepada sebagian warga negara, sesuai dengan kebijakannya. Makna pengelolaan oleh negara ini adalah adanya kekuasaan yang dimiliki negara untuk mengelolanya semisal harta fai, kharaj, jizyah dan sebagainya.

Meskipun harta milik umum dan milik negara pengelolaannya dilakukan oleh negara, namun ada perbedaan antara kedua bentuk hak milik tersebut. Harta yang termasuk milik umum pada dasamya tidak boleh diberikan negara kepada siapapun, meskipun negara dapat membolehkan kepada orang-orang untuk mengambil dan memanfaatkannya. Berbeda dengan hak milik negara di mana negara berhak untuk memberikan harta tersebut kepada individu tertentu sesuai dengan kebijakan negara. Harta kekayaan sejatinya adalah milik Allah Subhanahu Wa Ta'ala.

Dengan begitu, berarti harta kekayaan memiliki fungsi sosial yang tujuannya adalah kesejahteraaan masyarakat dan memenuhi kebutuhankebutuhan serta kemaslahatan-kemaslahatannya. Jadi dengan begitu, kepemilikan individu di dalam pandangan Islam merupakan sebuah fungsi sosial. Syaikh Abu Zahrah berpandangan, bahwa tidak ada halangan untuk mengatakan bahwa kepemilikan adalah fungsi sosial. ${ }^{15}$ Akan tetapi harus diketahui bahwa itu harus berdasarkan ketentuan Allah Swt bukan ketentuan para hakim, karena mereka tidaklah selalu orang-orang yang adil. ${ }^{16}$

\section{Waris dalam Islam}

Dari seluruh hukum yang ada dan berlaku dewasa ini di samping hukum perkawinan, maka hukum kewarisan merupakan bagian dari hukum kekeluargaan yang memegang peranan yang sangat penting, bahkan menentukan dan mencerminkan sistem dan bentuk hukum yang berlaku dalam masyarakat. ${ }^{17}$ Hal ini, disebabkan hukum kewarisan itu sangat erat kaitannya dengan ruang

\footnotetext{
${ }^{14}$ Nawi Bin Abdullah, “Konsep Kepemilikan dalam Islam”, dalam Jurnal Usuluddin, h. 25

${ }^{15}$ Ali Akbar, "Konsep Kepemilikan Dalam Islam “, dalam Jurnal Ushuluddin, h. 131.

${ }^{16}$ Ahmad Mukri Aji, Urgensi maslahat mursalah dalam dialektika pemikiran hukum Islam, Bogor: Pustaka Pena Ilahi, 2012, h. 77.

${ }_{17}$ M. IdrisRamulyo, Hukum Kewarisan Islam, (Jakarta: IND-HILL, CO, 1984), h.1
} 
lingkup kehidupan manusia bahwa setiap manusia pasti akan mengalami peristiwa, yang merupakan peristiwa hukum yang lazim yang disebut meninggal dunia.

Wujud warisan atau harta peninggalan menurut Hukum Islam sangat berbeda dengan wujud warisan menurut hukum barat sebagai mana diatur dalam BW maupun hukum waris adat.Warisan atau harta peninggalan menurut hukum Islam yaitu "sejumlah harta benda serta segala hak dari yang meninggal dunia dalam keadaan bersih". Artinya harta peninggalan yang diwarisi oleh para ahli waris adalah sejumlah harta benda serta segala hak, "setelah dikurangi dengan pembayaran hutang-hutang pewaris dan pembayaran-pembayaran lain yang diakibatkan oleh wafatnya sipeninggal waris" ${ }^{18}$

Pada dasarnya hukum kewarisan dalam Islam berlaku untuk seluruh umat Islam di seluruh dunia. Sungguhpun demikian, corak suatu negara Islam dan kehidupan di negara atau daerah tersebut memberi pengaruh berbeda atas hukum kewarisan, hal ini disebabkan oleh beberapa faktor, di antaranya:

Pertama: meskipun pada dasarnya Islam telah mengatur dasar hukum kewarisan secara terperinci dalam Al-Qur'an, jika terdapat kemuskilan pengertian telah dijelaskan oleh Nabi. Namun demikian, dalam hal pelaksanaan praktis terdapat masalah yang terdapat dalam Al-Qur'an dan belum sempat dijelaskan oleh Nabi, sehingga hukum menjadi terbuka. ${ }^{19}$

Kedua: bahwa ilmu hukum termasuk hukum Islam, di mana hukum waris ada di dalamnya, adalah tergolong ilmu sosial dan bukan ilmu eksakta. Oleh karena itu, hukum waris tempat kemungkinan terjadinya perbedaan-perbedaan pendapat di antara para ahli hukum itu sendiri, terutama mengenai ayat-ayat yang memungkinkan adanya penafsira lebih dari itu. ${ }^{20}$ Berikut ini adalah istilah-istilah yang dipergunakan dalam kewarisan perdata:

Pewaris: Adalah orang yang meninggal dunia yang meninggaalkan harta kekayaan.

Ahli Waris: Adalah anggota keluarga orang yang meninggal dunia yang menggantikan kedudukan Pewaris dalam bidang hukum kekayaan karena meninggalnya Pewaris.

Hukum Waris: Adalah hukum yang mengatur mengenai apa yang harus terjadi dengan harta kekayaan seseorang yang meninggal dunia, mengatur

${ }^{18}$ Eman Suparman, HukumWaris Indonesia: Dalam Perspektif Islam, Adat, dan BW, (Bandung: PT RefikaAditama, 2007), h. 13.

${ }^{19}$ Muchit A. Karim, Probematika Hukum Kewarisan Islam Kontemporer di Indonesia, (Jakarta: Puslitbang Kehidupan Keagamaan Badan Litbang dan Diklat Kementrian Agama RI), h. 111.

${ }^{20}$ M.Idris Ramulyono, Perbandingan Pelaksana Hukum Kewarisan Menurut KUH Perdata dan Islam, (Jakarta: Sinar Grafika, 1994), h. 6. 
peralihan harta kekayaan yang ditinggalkan oleh seseorang yang meninggal, serta akibat-akibatnya bagi para ahli waris.

Harta Warisan: Adalah kekayaan yang berupa keseluruhan aktiva dan pasiva yang ditinggalkan Pewaris dan berpindah kepada para ahli waris. Keseluruhan kekayaan yang berupa aktiva dan pasiva yang menjadi milik bersama ahli waris disebut Boedel.

\section{Asas-Asas Hukum Kewarisan Islam}

Hal-hal yang terkait dengan asas-asas hukum kewarisan Islam dapat digali dari ayat-ayat hukum kewarisan serta sunah nabi Muhammad SAW. Asas-asas dapat diklasifikasikan sebagi berikut:21

\section{Asas Ijbari (Paksaan)}

Dalam hukum Islam, peralihan harta seseorang yang telah meninggal dunia kepada ahli warisnya yang masih hidup berlaku dengan sendirinya menurut ketetapan Allah, tanpa digantungkan kepada usaha dan kehendak pewaris maupun ahli warisnya. Cara peralihan seperti ini disebut asas ijbari. Atas dasar ini, pewaris tidak perlu merencanakan penggunaan dan pembagian harta peninggalannya setelah ia meninggal dunia kelak, karena dengan kematiannya harta yang ia miliki secara otomatis akan berpindah kepada ahli warisnya dengan peralihan yang sudah ditentukan. Kata ijbari secara leksikan mengandung arti paksaan (compulsory), yaitu melakukan sesuatu di luar kehendaknya sendiri. Unsur paksaan (ijbari) ini terlihat dari segi ahli waris yang berhak menerima harta warisan beserta besarnya penerimaan yang diatur dalam ayat-ayat al-Qur' an yaitu surat an-Nisa ayat 11, 12, dan 176. Bentuk ijbari dari segi jumlah yang diterima, tercermin dari kata mafrudan, bagian yang telah ditentukan. Istilah ijbari direfleksikan sebagai hukum mutlak (compulsary law).

\section{Asas Bilateral}

Yang dimaksud dengan asas bilateral dalam hukum kewarisan Islam adalah seseorang menerima hak kewarisan bersumber dari kedua belah pihak kerabat, yaitu dari garis keturunan perempuan maupun keturunan laki-laki. ${ }^{22}$ Asas kebilateralan itu mempunyai 2 (dua) dimensi saling mewarisi dalam alQur'an surah An-Nisa/4 ayat 7, 11, 12, dan 176, yaitu: (1) antara anak dengan orang tuanya, dan (2) antara orang yang bersaudara bila pewaris tidak mempunyai anak dan orang tua. Hal ini di uraikan sebagai berikut:23

${ }^{21}$ Suhardi K Lubis dan Komis Simanjuntak, Hukum Waris Islam Lengkap dan Praktis, (Jakarta: Sinar Grafika, 1995) h. 37.

22 Suhrawardi Lubis dan Komis Simanjuntak, Hukum Waris Islam Lengkap dan Praktis, Cetakan kedua, h. 40.

${ }^{23}$ Zainuddin Ali, Pelaksanaan Hukum Waris di Indonesia, h. 54. 
Pertama; Dimensi saling mewarisi antara anak dengan orang tuanya. Dalam al-Qur'an surah An-Nisa ayat 7 ditegaskan bahwa laki-laki dan perempuan berhak mendapat harta warisan dari ibu-ayahnya. Demikian juga dalam garis hukum surah An-Nisa ayat 11 ditegaskan bahwa anak perempuan berhak menerima warisan dari orang tuanya sebagaimana halnya dengan anak laki-laki dengan perbandingan bagian seorang anak laki-laki sama dengan perempuan. Dengan demikian juga dalam garis hukum surah An-Nisa/4 ayat 11, ditegaskan bahwa ayah dan ibu berhak mendapat warisan dari anaknya, baik laki-laki maupun perempuan, sebesar seperenam, bila pewaris meninggalkan anak. ${ }^{24}$

Kedua; Dimensi saling mewarisi antara orang yang bersaudara juga terjadi bila pewaris tidak mempunyai keturunan atau orang tua. Kedudukan saudara sebagai ahli waris dalam hukum al-Qur'an surah An-Nisa ayat 12, ditentukan bahwa bila seorang laki-laki mati punah dan mempunyai saudara, maka saudaranya (saudara laki-laki atau saudara perempuan) berhak mendapat harta warisannya. Demikian juga garis hukum surat An-Nisa/4 ayat 12, bila pewaris yang mati punah seorang perempuan dan mempunyai saudara, maka saudaranya (laki-laki atau perempuan) berhak menerima harta warisannya. Selain itu, garis hukum al-Qur'an surah An-Nisa/4 ayat 176 menegaskan bahwa seorang laki-laki yang tidak mempunyai keturunan, sedangkan ia mempunyai saudara perempuan, saudaranya yang perempuan itulah yang berhak menerima warisannya. Demikian juga bila seorang laki-laki yang tidak mempunyai keturunan, sedangkan ia mempunyai saudara laki-laki, saudaranya yang laki-laki itulah yang berhak menerima harta warisannya. ${ }^{25}$

\section{Asas Individual}

Asas individual adalah setiap ahli waris (secara individu) berhak atas bagian yang didapatkannya tanpa terikat kepada ahli waris lainnya (sebagaimana halnya dengan pewaris kolektif yang dijumpai di dalam ketentuan hukum adat). ${ }^{26}$ Seperti adat masyarakat Minangkabau di Sumatera Barat. ${ }^{27}$ Dengan demikian, bagian yang diperoleh ahli waris dari harta pewaris dimiliki secara perorangan, dan ahli waris yang lainnya tidak ada sangkut paut sama sekali dengan bagian yang diperolehnya tersebut, sehingga individu masing-masing ahli waris bebas menentukan (berhak penuh) atas bagian yang diperolehnya.

\section{Asas Keadilan Berimbang}

Asas keadilan yang dimaksud harus ada keseimbangan antara hak yang diperoleh seseorang dari harta warisan dengan kewajiban atau beban biaya kehidupan yang harus ditunaikannya. Laki-laki dan perempuan misalnya,

24 Zainuddin Ali, Pelaksanaan Hukum Waris di Indonesia, h. 54-55.

${ }^{25}$ Zainuddin Ali, Pelaksanaan Hukum Waris di Indonesia, h. 55.

${ }^{26}$ Suhrawardi Lubis dan Komis Simanjuntak, Hukum Waris Islam Lengkap dan Praktis, Cetakan kedua, h. 40.

${ }^{27}$ Abdul Ghofur Anshori, Filsafat Hukum Kewarisan Islam, h. 34-35. 
mendapat bagian yang sebanding dengan kewajiban yang dipikulnya masingmasing (kelak) dalam kehidupan kelurga dan masyarakat. Seorang laki-laki menjadi penanggung jawab dalam kehidupn keluarga, mencukupi keperluan hidup anak dan istrinya sesuai (QS. 2: 233) dengan kemampuannya.Tanggung jawab merupakan kewajiban yang harus dilaksanakan, terlepas dari persoalan apakah istrinya mampu atau tidak, anak-anaknya memerlukan bantun atau tidak. $^{28}$

\section{Kewarisan Akibat Kematian}

Asas akibat kematian dalam hukum kewarisan Islam berarti kewarisan ada kalau ada yang meninggal dunia, kewarisan ada sebagai akibat dari meninggalnya seseorang. ${ }^{29}$ Bahwa peralihan harta seseorang kepada orang lain berlaku setelah yang mempunyai harta tersebut meninggal dunia dan selama harta itu tidak dapat beralih kepada orang lain. ${ }^{30}$ Dengan perkataan lain, harta seseorang tidak dapat beralih (dengan pewarisan) seandainya dia masih hidup. Walaupun ia berhak untuk mengatur hartanya, hak tersebut semata-mata hanya sebatas keperluannya semasa ia masih hidup, dan bukan untuk penggunaan harta tersebut sesudah ia meninggal dunia. ${ }^{31}$

\section{Asas Tandhidh}

Asas tandhidh kelihatannya layak untuk dipertimbangkan dalam pembagian harta warisan, terutama terhadap mauruts/tirkah yang ragam dari segi bentuk dan nilai. Misalnya Tuan Muhammad meninggal dunia dengan harta peninggalan berupa sebuah bangunan ruko di Mangga Dua Jakarta, satu bangunan ruko di Jambu Dua Bogor, tanah sawah seluas 10 hektar di Jonggol, tiga buah mobil dengn merk Jaguar, Alpard, dan Avanza, dan tanah seluas 10 hektar di Pamengpeuk Garut. Maka ahli waris Tun Muhammad atau juru taksir yang ditunjuk harus menaksir terlebih dahulu seluruh harta warisan ke dalam bentuk rupiah (nuqud), pembagian harta warisan dilakukan setelah dilakukan penaksiran sehingga sangat mungkin luas tanah atau bangunan yang diterima oleh waris berbeda-beda tapi relatitif sama dari segi nilai/harga setelah dilakukan perhitungan porsi/kadar bagian masing-masing ahli waris sesuai dengan derajat yang dimilikinya. Hal itu dilakukan karena harga ruko di Manga Dua dan di Jambu Dua berbeda, harga tanah di Jonggol berbeda dengan harga tanah di

${ }^{28}$ Muchit A. Karim, (ed), 2010. Pelaksanaan Hukum Waris di Kalangan Umat Islam Indonesia, Badan Litbang dan Diklat Puslitbang Kehidupan Keagamaan, h.99

${ }^{29}$ Zainuddin Ali, Pelaksanaan Hukum Waris di Indonesia, h. 58.

${ }^{30}$ Amir syarifuddin, Hukum Kewarisan Islam, h. 12.

31 Suhrawardi Lubis dan Komis Simanjuntak, Hukum Waris Islam Lengkap dan Praktis, Cetakan kedua, h. 41. 
Pameungpeuk, dan harga mobil yang diwariskan juga berbeda-beda karena perbedaan merk. ${ }^{32}$

\section{Waris Dalam KUHPerdata}

\section{Memahami Waris dalam KUHPerdata}

Hukum waris menurut BW berlaku asas: “apabila seseorang meninggal dunia, maka seketika itu juga segala hak dan kewajiban beralih kepada ahli warisnya". Hak-hak dan kewajiban dimaksud, yang beralih kepada ahli waris adalam termasuk ruang lingkup harta kekayaan atau hanya hak dan kewajiban yang dapat dinilai dengan uang.

Ciri khas hukum waris perdata Barat atau BW antara lain: adanya hak mutlak dari para ahli waris masing-masing untuk sewaktu-waktu menuntut pembagian dari harta warisan. Hal itu berarti bila seseorang ahli waris menuntut pembagian harta warisan di pengadilan, maka tuntutan dimaksud, tidak dapat ditolak oleh ahli waris yang lainnya. Hal ini berdasarkan ketentuan pasal 1066 BW sebagai berikut. ${ }^{33}$

a. Seseorang yang mempunyai hak atas sebagian dari harta peninggalan tidak dapat dipaksa untuk membiarkan harta benda peninggalan dalam keadaan tidak terbagi-bagi di antara para ahli waris yang ada.

b. Pembagian harta benda peninggalan itu selalu dapat dituntut walaupun ada perjanjian yang melarang hal itu.

c. Perjanjian penangguhan pembagian harta peninggalan dpat saja dilakukan hanya beberapa waktu tertentu.

d. Perjanjian penangguhan pembagian hanya berlaku mengikat selama lima tahun, namun dapat diperbaruhi jika masih dikehendaki oleh para pihak.

Dalam kitab undang-undang hukum perdata di Indonesia ada dua cara untuk mendapatkan harta warisan, yaitu ${ }^{34}$

a. Sebagai ahli waris menurut ketentuan undang-undang (ab intestato)

b. Karena seorang ditunjuk dalam surat wasiat (testamentair)

Pasal 834 BW mengungkapkan bahwa seorang ahli waris berhak untuk menuntut segala apa saja yang termasuk harta peninggalan agar diserahkan

${ }^{32}$ Muchit A. Karim, (ed), 2010. Pelaksanaan Hukum Waris di Kalangan Umat Islam Indonesia,

${ }^{33}$ A. Pitlo, Hukum Waris Menurut Kitab Undang-undang Hukum Perdata Belanda, Terjemahan M.Isa Arief, Jakarta: Intermasa, 1979, h. 10.

${ }^{34}$ Eman Suparman, Hukum Waris Indonesia dalam Perspektif Islam, adat, dan BW, Bandung: PT.Refika Aditama, 2014, cet. Keempat, h. 31 
kepadanya, berdasarkan haknya sebagai ahli waris. Pemilik hak dimaksud mirip dengan hak seorang pemilik benda.

Hak menuntut ahli waris dimaksud, hanya sebatas pada seseorang yang menguasai suatu harta warisan dengan maksud untuk memilikinya. Jadi, penuntutan ini tidak dapat dilakukan terhadap pelaksanaan wasiat (executeur testamentair), seorang kurator atas harta peninggalan yang tidak terurus dan penyewa dari benda warisan. ${ }^{35}$

\section{Ahli Waris Sistem Bw (Burgerlijk Wetboek) ${ }^{36}$ dan Porsi Bagiannya}

Ahli waris menurut peraturan perundang-undangan, yaitu istri atau suami yang ditinggalkan dan keluarga sah atau tidak sah dari pewaris. Ahli waris menurut peraturan undang-undang atau ahli waris ab intesto berdasarkan hubungan darah terdapat berapa golongan sebagai berikut. ${ }^{37}$

Pertama; Golongan pertama adalah keluarga dalam garis lurus kebawah, meliputi anak-anak beserta keturunannya serta suami dan/atau istri yang ditinggalkan/yang hidup paling lama. Suami atau istri yang hidup palinglama ini diakui sebagai ahli waris pada tahun 1935, sedangkan sebelumnya suami/istri tidak saling mewarisi. Bagian golongan pertama yang meliputi anggota keluarga dalam garis lurus kebawah, yaitu anak-anak beserta keturunanya, janda dan/atau duda yang ditinggalkan/yang hidup palinglama, masing-masing memperoleh bagian yang sama. Oleh karena itu, bila terdapat empat anakdan janda maka mereka masing-masing mendapat hak seperlima bagian dari harta warisan. Apabila salah seorang anak telah meninggal dunia lebih dahulu dari pewaris tetapi mempunyai lima orang anak, yaitu cucu-cucu perwaris, maka bagian anak yang seperlima dibagi diantara anak-anaknya yang menggantikan kedudukan ayahnya yang telah meninggal (dalam sistem hukum waris BW disebut plaatsvervulling dan dalam sistem hukum waris Islam disebut ahli waris pengganti dan dalam hukum waris adat disebut ahli waris pasembei) sehingga masingmasing cucu memperoleh seperdualima bagian. Lain halnya jika seorang ayah meninggal dan meninggalkan ahli waris yang terdiri atas seorang anak dan tiga orang cucu, maka hak cucu terhalang daari anak (anak menutup anaknya untuk menjadi ahli waris). ${ }^{38}$

Kedua; Golongan kedua adalah keluarga dalam garis lurus ke atas, meliputi orang tua dan saudara, baik laki-laki maupun perempuan, serta keturunannya. Bagi orang tua ada peraturan khusus yang menjamin bahwa

\footnotetext{
${ }^{35}$ Ibrahim Hosen, “Tinjauan Perbandingan Mazhab Fiqih Tentang Nikah, Talak, Rujuk, dan Kewarisan ", dalam Majalah Ihja 'Ulumudin, h. 83

${ }^{36}$ selanjutnya ditulis BW.

${ }^{37}$ Surini Ahlan Sjarif dan Nurul Elmiyah, Hukum Kewarisan Perdata Barat Pewarisan Menurut Undang-undang, Edisi Pertama, h.87-92.

38 Surini Ahlan Sjarif dan Nurul Elmiyah, Hukum Kewarisan Perdata Barat Pewarisan Menurut Undang-undang, Edisi Pertama, h.87-92.
} 
bagian mereka tidak akan kurang seperempat bagian dari harta peninggalan, walaupun mereka menjadi ahli waris bersama saudara pewaris. Oleh karena itu bila terdapat tiga orang sudara yang menjadi ahli warris bersama-sam dengan ayah dan ibu, maka ayah dan ibu masing-masing akan memperoleh seperempat bagian dari seluruh harta warisan, sedangkan separuh dari harta warisan itu akan diwarisi oleh tiga orang saudara yang masing-masing seperenam bagian. Jika ibu atau ayah salah salah seorang sudah meninggal dunia maka yang hidup paling lama akan memperoleh sebagai berikut:

1) Setengah bagian dari seluruh harta warisan, bila ia menjadi ahli waris bersama-sama dengan seorang saudaranya, baik laki-laki maupun perempuan, sama saja.

2) sepertiga bagian dari seluruh harta warisan, bila ia menjadi ahli waris bersama-sama dengan dua orang sudara pewaris.

3) Seperempat bagian dari seluruh harta warisan, bila ia menjadi ahli waris bersama-sama dengan tiga orang atau lebih saudara pewaris. ${ }^{39}$

\section{Kesimpulan}

Hukum kewarisan merupakan hukum yang mengatur tentang perpindahan hak pemilikan harta peninggalan (tirkah) pewaris, Oleh karena itu kewarisan sangat erat kaitannya dengan ruang lingkup kehidupan manusia, sebab setiap manusia pasti mengalami peristiwa hukum yang disebut kematian.

Hukum Islam telah meletakan aturan kewarisan dan hukum mengenai harta benda dengan sebaik-baiknya dan seadil-adilnya. Sebab Islam menetapkan hak milik seseorang atas harta, baik laki-laki maupun perempuan seperti perpindahan harta kepada ahli warisnya setelah ia meninggal dunia.

Dalam hukum Islam pembagian harta peninggalan akan dibagi setelah bersih dari pengurusan jenazah, utang, zakat dan wasiat, utang-utang pewaris sebagai pasiva dari harta peninggalan. Begitu pula dalam hal bagian masingmasing ahli waris, dalam hukum Islam membedakan bagian ahli waris antara lakilaki dan perempuan.

Sistem hukum waris BW tidak mengenal harta asal dan harta perkawinan atau harta gono gini. Sebab harta warisan dalam BW dari siapapun juga merupakan kesatuan yang secara bulat dan utu dalam keseluruhan akan beralih dari tangan si peninggal harta atau pewaris kepada seluruh ahli warisnya. Hal ini berarti dalam sistem pembagian harta warisan dalam BW tidak dikenal perbedaan pengaturan atas dasar asal usul harta yang ditinggalkan oleh pewaris seperti yang diungkapkan dalam pasal 849 BW, "undang-undang tidak memandang akan sifat

${ }^{39}$ Surini Ahlan Sjarif dan Nurul Elmiyah, Hukum Kewarisan Perdata Barat Pewarisan Menurut Undang-undang, Edisi Pertama, h.87-92. 
atau asal dari barang-barang dalam suatu harta peninggalan untuk mengatur pewarisan terhadapnya."

\section{Daftar Pustaka}

Abu Zahrah, Muhammad, Ahkam al-Tirkah wa al-Mawarits, Kairo: Dar al-Fikr al'arabi, t.th.

Aji, Ahmad Mukri, Urgensi maslahat mursalah dalam dialektika pemikiran hukum Islam, Bogor: Pustaka Pena Ilahi, 2012

Afif, A.Wahab, Fiqh Mawaris, Serang: Yayasan Ulumul Quran,1994.

Bashori, Abu Hamzah Agus Hasan, "Relevansi Hukum Waris Islam Bias Isu Gender, Egalitarianisme, Pluralisme, dan HAM," Cet. IX. t, tp: al- Sunnah, 2005.

Dja'far, Moh., Polemik Hukum Waris. Jakarata: Kencana Mas Publishing House, 2007.

Ghofur, Abdul Anshari, Filsafat Hukum Kewarisan Islam, Yogyakarta: UII Press, 2005.

Hazairin, Hukum Kewarisan Bilateral menurut Al-Qur'an dan Hadis. Jakarta: Tinta Mas, 1982.

Ismail, M. Shuhudi, Kaidah Keshahihan Sanad Hadis. Jakarta: Bulan Bintang, 1988.

Jandi, al-, Muhammad al-Syahat, Al Mirats fi Syari ah al-Islam, Kairo: Dar al-Fikr al'arabi, t.th.

Karim, Muchit A., Probematika Hukum Kewarisan Islam Kontemporer di Indonesia. Jakarta: Puslitbang Kehidupan Keagamaan Badan Litbang dan Diklat Kementrian Agama RI.

Lubis, Suhardi K dan Komis Simanjuntak, Hukum Waris Islam Lengkap dan Praktis. Jakarta: Sinar Grafika, 1995.

Masalik, Mabadlul, Pengantar Ilmu Faroidh, terjemahan Iddatul Faridh, diterjemahkan oleh Dimayati Romli, Muhammad Ma'shum Zaini Al Hasyimy, Pasuruan: GBI, 1994.

Parman, Ali, Kewarisan dalam Al-Qur'an: Suatu Kajian Hukum dengan Pendekatan Tafsir Tematik. Jakarta: PT Raja Grafindo Persada, 1995.

Pitlo, A., Hukum Waris Menurut Kitab Undang-undang Hukum Perdata Belanda, Terjemahan M. Isa Arief. Jakarta: Intermasa, 1979.

Qurtubi, Sumanto Al, Era Baru Figh Indonesia, Yogyakarta: Cermin, 1999.

Ramulyono, M. Idris, Perbandingan Pelaksana Hukum Kewarisan Menurut KUH Perdata dan Islam. Jakarta: Sinar Grafika, 1994. 
Hukum Kewarisan Islam. Jakarta: IND-HILL, CO, 1984.

Suparman, Eman, Hukum Waris Indonesia dalam Perspektif Islam, adat, dan BW. Bandung: PT. Refika Aditama, 2014.

Syarifuddin, Amir, Hukum Kewarisan Islam. Jakarta: Kencana, 2004.

Thalib, Saajuti. Hukum Kewarisan Islam Indonesia. Cet. IV. Jakarta: Sinar Grafika, 2004.

Usman, Suparman, Ikhtisar Hukum Waris Menurut KUH Perdata (BW), Jakarta: Darul Ulum Press, 1993.

Washil, Nashr Farid Muhammad, Figh al-Mawarits wa al-Washiyyah fi al-syari ah alIslamiyyah: Dirasah Muqaranah, Iskandariyah: al-Maktab al-Taufiqiyyah, t.th.

Zahari, Ahmad, Tiga Versi Hukum Kewarisan Islam: Syafi I, Hazairin dan KHI, Jakarta: PT. Gunung Agung, 1997.

Zuhaili, Wahbah. al-Figh al-Islami wa dilatuhu. cet IV. Damaskus: Daar al-Fikr, 2004. 